2018-02

\title{
Energy and economic performance of rooftop PV panels in the hot and dry climate of Iran
}

\section{Korsavi, Sepideh Sadat}

http://hdl.handle.net/10026.1/18023

\begin{abstract}
10.1016/j.jclepro.2017.11.026
Journal of Cleaner Production

Elsevier BV
\end{abstract}

All content in PEARL is protected by copyright law. Author manuscripts are made available in accordance with publisher policies. Please cite only the published version using the details provided on the item record or document. In the absence of an open licence (e.g. Creative Commons), permissions for further reuse of content should be sought from the publisher or author. 


\title{
Energy and economic performance of rooftop PV panels in the hot and dry climate of Iran
}

\author{
Sepideh Sadat Korsavi a , Zahra Sadat Zomorodian ${ }^{\text {b }}$, Mohammad Tahsildoost ${ }^{\text {b, * }}$ \\ ${ }^{a}$ Centre for the Built and Natural Environment, Coventry University, UK \\ ${ }^{\mathrm{b}}$ Department of Construction, School of Architecture and Urban Planning, Shahid Beheshti University, Tehran, Iran
}

\section{A R T I C L E I N F O}

\section{Article history:}

Received 25 August 2017

Received in revised form

3 November 2017

Accepted 5 November 2017

Available online 8 November 2017

\section{Keywords:}

PV panels

Economic performance

Energy performance

Actual and subsidized prices

Performance optimization

\begin{abstract}
A B S T R A C T
Photovoltaic (PV) Panels, one of the more promising renewable energy technologies, are growing rapidly nowadays, especially in developed countries. However, these systems have not achieved public acceptance in some countries due to low energy efficiency and poor economic performance, especially in countries which are subsidized in energy tariffs. In this paper, the energy and economic performance of fourteen rooftop PV systems with the power of $5 \mathrm{~kW}$ in the hot and dry climate of Iran are assessed by monitoring the total annual energy production and simulation. The monitored data is used to analyze systems' economic performance via Pay-Back Period (PBP), Net Present Value (NPV), Return of Investment (ROI) and Levelized Cost of Energy (LCOE). Results show that single array configuration systems have the maximum energy production while dividing the system decreases the production. Economic analysis shows that the average PBP is 11.6 years under actual price of electricity $(0.21 \$)$, however it is 46.9-50.5 years under subsidized average tariffs. ROI values range from 2.6 to 3.2 with the average of 2.9 for actual prices. Under subsidized prices, the cash generated by investment cannot even offset the costs that the investment requires during its lifetime with NCF and NPV being both negative. Overall, the systems are not economically beneficial under subsidized average tariffs in Iran, which discourages private and public sectors to investment on these systems. Environmentally, each PV system can averagely reduce $500 \mathrm{~kg} \mathrm{CO}_{2}$ emission in the first year of installation and fourteen of them can approximately reduce $1,613,900 \mathrm{~kg}$ of $\mathrm{CO}_{2}$ emission during life time of $\mathrm{PV}$ panels.
\end{abstract}

(c) 2017 Elsevier Ltd. All rights reserved.

\section{Introduction}

The world's dependence upon fossil fuels for its energy needs results in high $\mathrm{CO}_{2}$ emissions. Building industry accounts for approximately one third of global energy use and one fifth of global greenhouse gas emissions (IEA, 2016). By using renewable energy sources (e.g. solar, wind, etc.) for generating electricity, which is ranked second among world's total final energy consumption, considerable amount of greenhouse gas (GHG) emission can be reduced (Adam and Apaydin, 2016; Coughlin and Kandt, 2011). Although a large amount of GHG is released during manufacturing of PV panels (Al-Salaymeh et al., 2010; Kim et al., 2014), generated electricity reduces emissions by at least $89 \%$ compared to grid electricity (Kannan et al., 2006); convectional grid electricity

\footnotetext{
* Corresponding author.

E-mail addresses: korsavis@uni.coventry.ac.uk (S.S. Korsavi),Z zomorodian@ sbu.ac.ir (Z.S. Zomorodian), M_tahsildoost@sbu.ac.ir (M. Tahsildoost).
}

sources use much primary energy in the process of production, transmitting and distribution (Fthenakis et al., 2008).

Iran is ranked $30^{\text {th }}$ among countries with the highest electricity energy consumption; the total electricity energy consumed is 186 Terawatt-hour (TWh), with $8-9 \%$ increase per year. Due to government's subsidies, electricity price is much lower in Iran than that in most of the world countries, while Iran is ranked second among OPEC with a potential to export natural gas to Europe and Asia. The electricity is mainly generated by fossil fuels (94\%), about $6 \%$ by hydro, and less than $1 \%$ by renewable energy resources (Abbaspour and Hennicke, 2005; Moshiri, 2013; Kazemi and Zahedi, 2002). To address environmental issues and to increase gas export applying renewable energy seems necessary in Iran ( $G$. German Solar Association and BSW-Solar,Berlin, 2016).

Photovoltaics are known as a common renewable electricity generation system. Iran has a great potential for solar radiation; more than 300 clear sunny days a year on two third of the land, and the average solar radiation of $19.23 \mathrm{MJ} / \mathrm{m}^{2}$ and 2800 radiation hours per year (Kazemi and Zahedi, 2002). Horizontal radiation at 


\begin{tabular}{|llll|}
\hline \multicolumn{2}{|c|}{ Abbreviations and nomenclature } & CED & Carbon dioxide Emission Reduction \\
PBP & Pay-Back Period & PV & Photovoltaic \\
NPV & Net Present Value & NOCT & Nominal Operating Cell Temperature \\
NCF & Net Cash Flow & $\mathrm{P}_{\mathrm{s}}$ & total output measured energy $(\mathrm{kWh})$ \\
ROI & Return of Investment & $\mathrm{I}$ & Irradiance $\left(\mathrm{kWh} / \mathrm{m}^{2}\right)$ \\
LCOE & Levelized Cost of Energy & $\mathrm{A}$ & area of array $\left(\mathrm{m}^{2}\right)$ \\
GHG & greenhouse gas & $\mathrm{E}_{\mathrm{s}}$ & efficiency of the panel \\
TWh & Terawatt-hour & $\mathrm{C}_{0}$ & initial investment cost \\
FIT & Feed-in Tariffs & $\mathrm{Ct}$ & net cash inflow during the period t \\
LCOE & Levelized cost of electricity & $\mathrm{N}_{\mathrm{y}}$ & Life time \\
PR & Performance Ratio & $\mathrm{i}$ & discount rate \\
PAE & Percentage of Annual Electricity & $\mathrm{O \& M}$ & operations and maintenance \\
& & & \\
\end{tabular}

some stations were recorded averagely higher than $500 \mathrm{~W} / \mathrm{m}^{2}$ in a year (Alamdari et al., 2012) which is economically viable for photovoltaic panels (El Chaar and Lamont, 2010), Fig. 1. Despite the high potential of solar power and serious need of new energy sources in near future, current economic situation and policies do not make PV systems popular in Iran. In addition to solar plants which belong to governmental energy producers, rooftop PV panels can be beneficial in local private sectors without any land use problems. In other words, spacious useless flat roof areas and considerable energy budgets in public services, governmental and semi-public buildings provide a good potential to use PVs as an economically beneficial approach.

Different aspects of photovoltaics have been the target of research in recent years, e.g., energy performance, economic performance, PV cell characteristics and Carbon footprints. However, it is uncertain to only consider financial aspects of installing PV systems (Orioli and Di Gangi, 2014). The economic performance of the energy generation is known as a determining factor in the development of these systems (Kandt, 2011; Rose et al., 2016), especially in countries with highly subsidized energy tariffs. A clear understanding of the relative cost-effectiveness and feasibility of different energy technologies is paramount in determining energy management policies for any nation (Esen and Yuksel, 2013; Esen

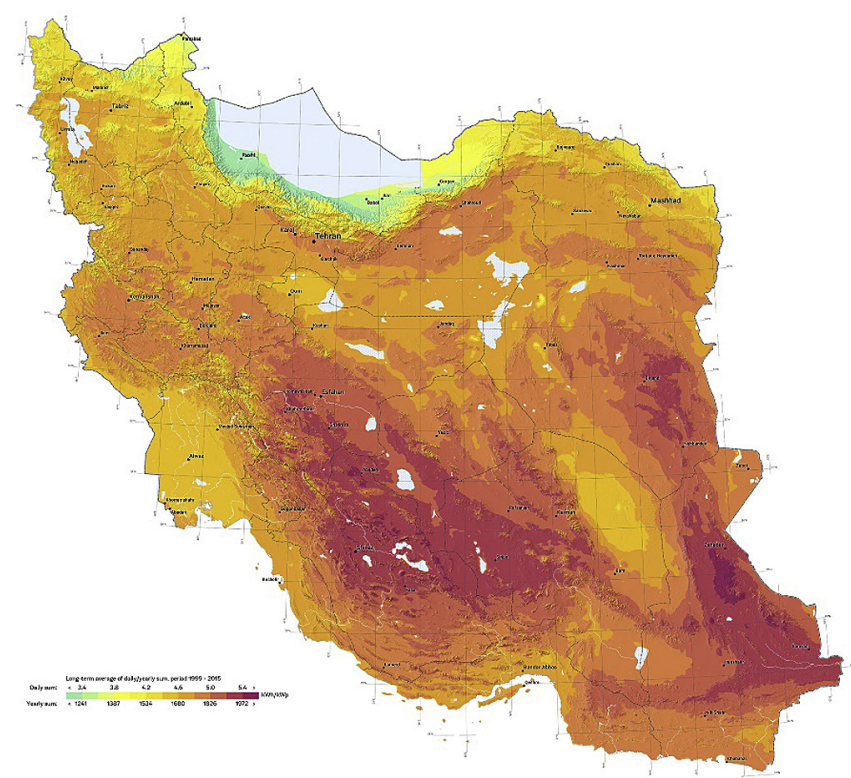

Fig. 1. Photovoltaic power potential in Iran (Retrieved from solargis, 2015). et al., 2017; Branker et al., 2011). Economic performance assessment methods have been introduced and defined in different studies (El Chaar and Lamont, 2010; Rose et al., 2016; Esen et al., 2006, 2007; Pillai et al., 2014). On the economic convenience of PV panels for private investors in Iran, the study by Abbaspour and Hennicke (2005) shows that they are not profitable even if 50 percent of the investments is subsidized (Abbaspour and Hennicke, 2005). Although the demand and incentives for renewable energy have been increasing (Branker et al., 2011) and the cost of PV systems has been reducing over the years (Coughlin and Kandt, 2011; Feldman et al., 2012; Curthoys, 2012), several studies show that the high initial costs of PV systems compared to the cost of fossil fuel electricity are still a deterrent for most consumers (Hsu, 2012; Ren et al., 2009). Furthermore, researches state that payback period is significantly influenced by efficiency, local price of electricity, and most importantly, capital cost (Ren et al., 2009). In order to increase customer's benefits, increasing grid electricity price, reducing PV systems' prices, and increasing inverter lifetime are required (Coughlin and Kandt, 2011; (Branker et al., 2011). Studies imply that Feed-in Tariffs (FIT) (Bernal-Agustín and Dufo-López, 2006; Hestnes, 1999), grants, and capital subsidies (Hsu, 2012) are also incentives for public and private sectors to install PV systems. The economic feasibility of PV projects is increasingly being evaluated using the levelized cost of electricity (LCOE) generation. Photovoltaics LCOE is reported from 0.12 to $0.78 \$ / \mathrm{kWh}$ in different countries (Branker et al., 2011; Quansah and Adaramola, 2016).

The commercial demand has led into the development of many PV analysis and planning software packages to predict the performance of grid connected photovoltaic (PV) system i.e., PVSYST, RETScreen, TRNSYS, PVSOL (Accuracy analysis of software for the estimation and planning of photovoltaic installations, 2014). Modol et al., used TRANSYS to model a grid connected PV system and compared the results with measured data (Quansah and Adaramola, 2016). Axaopoulos et al., studied the calculative accuracy of a few PV simulation softwares in comparison to the real electrical energy generated by a grid-connected $19.8 \mathrm{~kW}$ photovoltaic installation. Results displayed that the software packages tend to overestimate the global irradiation received by the PV modules but still significantly underestimate the electrical energy generated by the installation (Accuracy analysis of software for the estimation and planning of photovoltaic installations, 2014).

The objective of this study is to evaluate electricity generation, $\mathrm{CO} 2$ production, and economic performance of rooftop PV panels. To carry out the study, one-year monitored data of fourteen rooftop PV systems with the power of $5 \mathrm{~kW}$ on educational buildings was analyzed. Performance parameters calculated include: Performance Ratio (PR), Percentage of Annual Electricity (PAE), Carbon dioxide Emission Reduction (CED), Net Present Value (NPV), 


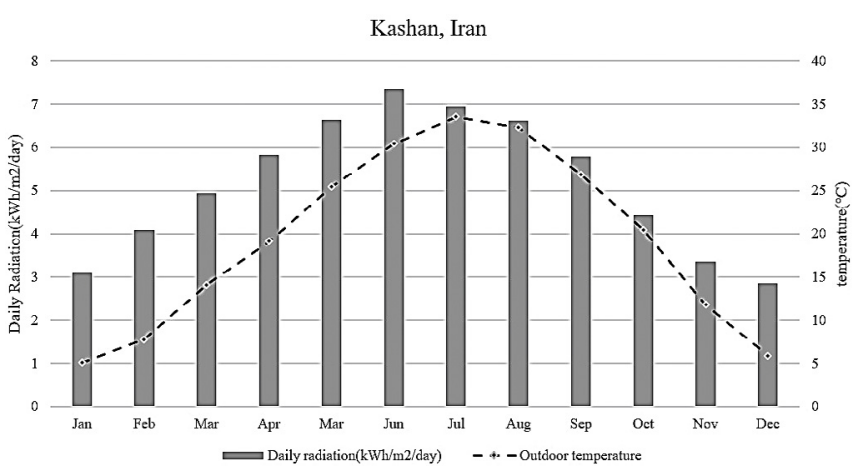

Fig. 2. Monthly horizontal solar radiation and average air temperature in Kashan.

Payback period (PBP), Return of Investment (ROI) and Levelized Cost of Electricity (LCOE). To provide reliable data for design and installation of PV panels, energy performance of studied PV systems has been modeled and compared to field results.

\section{Methodology}

\subsection{Case studies}

Rooftop PV panels in public schools in Kashan, Iran have been selected for this study to evaluate their economic and environmental performance. Kashan ( $\left.33^{\circ} 58^{\prime} 59^{\prime \prime} \mathrm{N} / 51^{\circ} 25^{\prime} 56^{\prime \prime} \mathrm{E}\right)$ climate is classified as BWh by the Köppen-Geiger system, with hot and dry climate and virtually no rainfall during the year. According to Kashan Weather Station, the sky of Kashan is 67\% clear, 24\% partly cloudy and $9 \%$ cloudy during a year (Chaharmahal Weather Station Website). Monthly horizontal solar radiation and average temperature in Kashan are shown in Fig. 2 (Irradiation data for every place on Earth). In 2014, the government funded solar PV projects in educational buildings all over the country, including 14 schools in Kashan. All schools are located within a 5-km radius from the city center, surrounded by urban buildings with the same average height and are occupied from 8:00 a.m. to 1:00 p.m., October to June. Electrical loads are mainly contributed to lighting systems; however, cooling systems account for most of the electrical load in May and June.

The methodology in this assessment contains 4 steps which are illustrated in methodology flowchart in Fig. 3: 1) Monitoring PV panels' power generation during a year 2) Simulating electricity generation 3. Energy and environment analysis and 4) Economic analysis.

\subsection{Monitoring}

Multi-crystalline silicon Panels, the most common available in the market, are used in these schools, described in Table 1. $5 \mathrm{~kW}$ PV panels are mounted on unshaded roofs at an angle equal to Kashan Latitude $\left(33^{\circ}\right)$ to have an efficient production in both summer and winter (Fig. 4).

A Sunny Tripower 15000 TL inverter, a SMA Sunny SensorBox with integrated solar radiation sensor and an external temperature sensor module were used to collect environmental data from PV systems on an hourly basis, which were then used for monitoring energy performance in each case. The solar irradiation sensors have been calibrated with the help of TES 1333R solar power meter. A DataQ- DI-245 data acquisitions system has been used to collect and process the data from the sensors and inverter. Data are averaged daily using the application program of the data acquisition system.

Total produced energy has been recorded from August 2014 for a year, Table 2. Annual electricity consumption of each school is obtained from electricity bills. Total energy generation, initial cost, unit panel cost and the percentage of the electricity consumption that is generated by PV systems are reported in Table 2 for each school. Low electricity generation in Iran and high energy demand of buildings and industries on the other hand, make it logical to produce electricity and sell it back to the local grid. Moreover, in case of educational buildings, the total generated electricity is sold

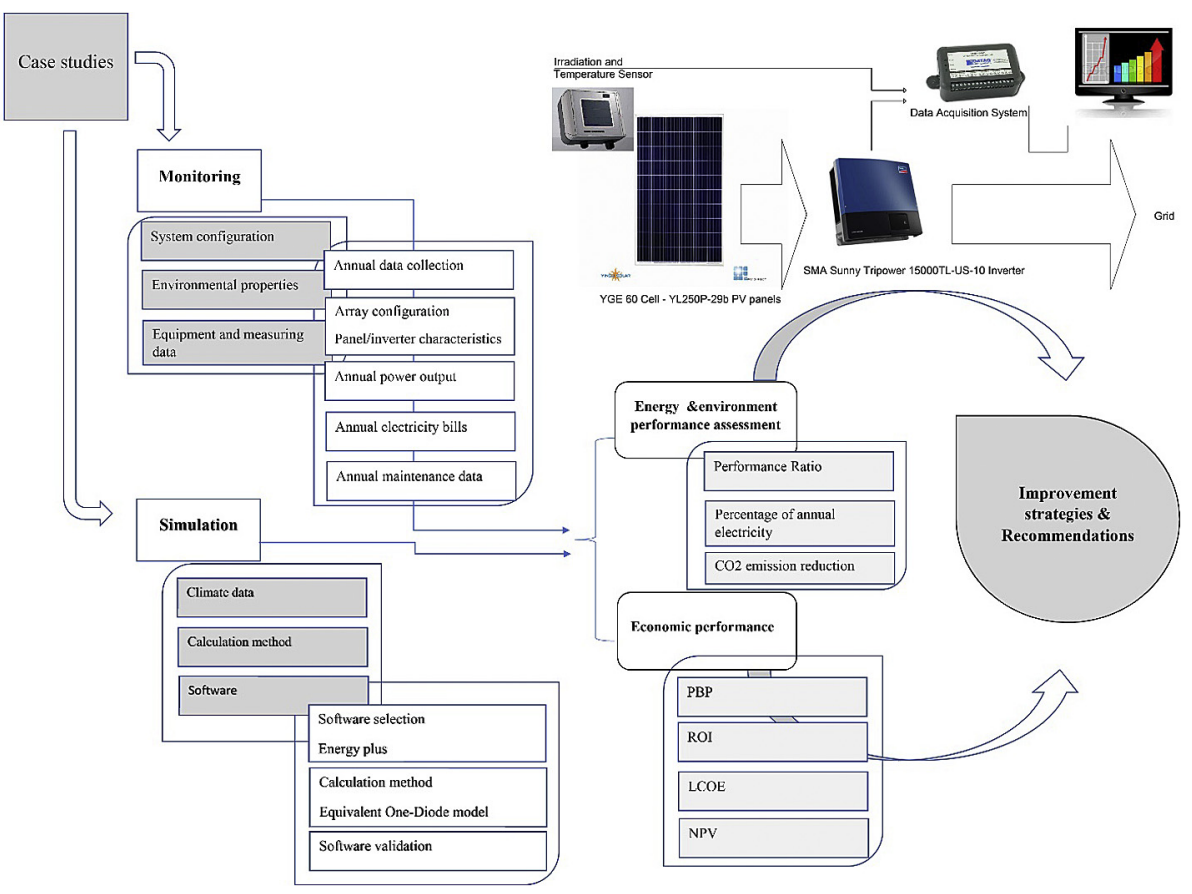

Fig. 3. Research Methodology flowchart. 
Table 1

Station identification and solar panel characteristics.

\begin{tabular}{|c|c|c|c|c|c|}
\hline \multicolumn{2}{|c|}{ Station Identification } & \multicolumn{4}{|l|}{ Solar Panel Characteristics } \\
\hline Continent & Asia & Panels' capacity (w) & 250 & Short circuit current (A) & $8 / 79$ \\
\hline Country & Iran & Panels' Type & YL250P-29b & Max system voltage (V) & 1000 \\
\hline Province & Isfahan & Related Max Power (w) & $250(\sim 0+5)$ & Rated efficiency (\%) & 13.65 \\
\hline City & Kashan & Related Voltage (V) & $30 / 4$ & Deterioration rate $(\%)$ & 0.7 \\
\hline Latitude & $33.98^{\circ}$ & Related Current (A) & $8 / 24$ & Project lifetime & 25 \\
\hline Longitude & $51.40^{\circ}$ & Max Series Fuse (A) & 15 & Test Conditions & AM $1 / 5,25^{\circ} \mathrm{C}, 1000 \mathrm{w} / \mathrm{m}^{2}$ \\
\hline Elevation & $946.37 \mathrm{M}$ & Open circuit voltage (V) & $38 / 4$ & Invertors & 5 kW SMA Germany \\
\hline
\end{tabular}

to the utility grid because of high guaranteed purchase in PV development plan policies (21 cent) and the subsidized educational building electricity tariffs $(0.3-1.1$ cent).

\subsection{Simulation}

PV simulations are carried out for different designs from standalone, off grid system to grid connected building integrated photovoltaics by professional photovoltaic system design software (e.g., RETScreen, PVSYST PV*SOL Expert, PolySun and HOMER) and also whole building dynamic energy simulation software (e.g., TRNSYS and EnergyPlus). For the purpose of this research, annual power generation of the rooftop panels have been modeled by two tools: Energyplus, a whole building energy simulation program that engineers, architects, and researchers use to model energy consumption and generation in buildings. In order to assess the accuracy of results, PV*SOL is also used to predict annual energy production of the used panels. PV*SOL computes average frequency of the modules shadowed by the objects and shows the results graphically, helping users to optimize panel allocation depending on shading position.

Both tools use the same method for predicting electricity generated by photovoltaic panels. The equivalent one-diode method uses empirical relationships to more accurately predict PV operating performance based on dynamic parameters, such as incident radiation and cell temperature (Griffith and Ellis, 2004). This model is also known as the four or five parameters TRNSYS model. The four-parameter equivalent circuit is shown in Fig. 5 . V is the load voltage and I is the current flowing through the load and $\mathrm{PV}$. The "four parameters" in the model are $\mathrm{I}_{\mathrm{L}}$ ref (Module photocurrent at reference conditions), $\mathrm{I}_{\mathrm{D}}$ ref (Diode reverse saturation current at reference conditions), $g$ (Module shunt resistance) and $R_{S}$ (Module series resistance). These are empirical values that cannot be determined directly through physical measurement. Both software calculates these values from manufactures' catalog data i.e., short circuit current, open circuit voltage, voltage at maximum power, current at maximum power, temperature coefficient of short circuit current, temperature coefficient of open circuit voltage, number of cells in series per module, cell temperature at NOCT (Nominal Operating Cell Temperature) condition, and module area (U.S. Department of Energy, 2012). This model is applied and validated in many studies, reporting 5-8\% error when comparing predicted energy generation to the actual data (Accuracy analysis of software for the estimation and planning of photovoltaic installations, 2014). In order to decrease simulation errors, monthly global irradiation on the horizontal plane and ambient temperature recorded during monitoring period were used in both software.

\section{Results}

\subsection{Energy performance}

Monitored and simulated electricity generation of PV systems are presented in Fig. 6. Although all used PV systems have a capacity of $5 \mathrm{~kW}$, outputs differ modestly based on the arrangement, Table 2 and Fig. 6 . Those arranged in $1 \times 20$ perform better than those in $2 \times 10$ or $4 \times 5$ arrays. The arrangements differ significantly in different schools with regards to their roof shape and size. Generally, $5 \mathrm{~kW}$ systems arranged $1 \times 20$ are more efficient as they generate more energy and have lower initial cost (lower costs of installation and wiring). The difference between maximum and minimum generated electricity is $12.2 \%$, with the maximum of $9428 \mathrm{kWh}$ per year for $1 \times 20$ and minimum of $8267 \mathrm{kWh}$ for $10 \times 5 \times 5$, Table 2 .

As atmospheric conditions also affect system performance, irradiation and maximum temperature of the panels were logged daily. Fig. 7 shows averaged annual temperature and irradiation of

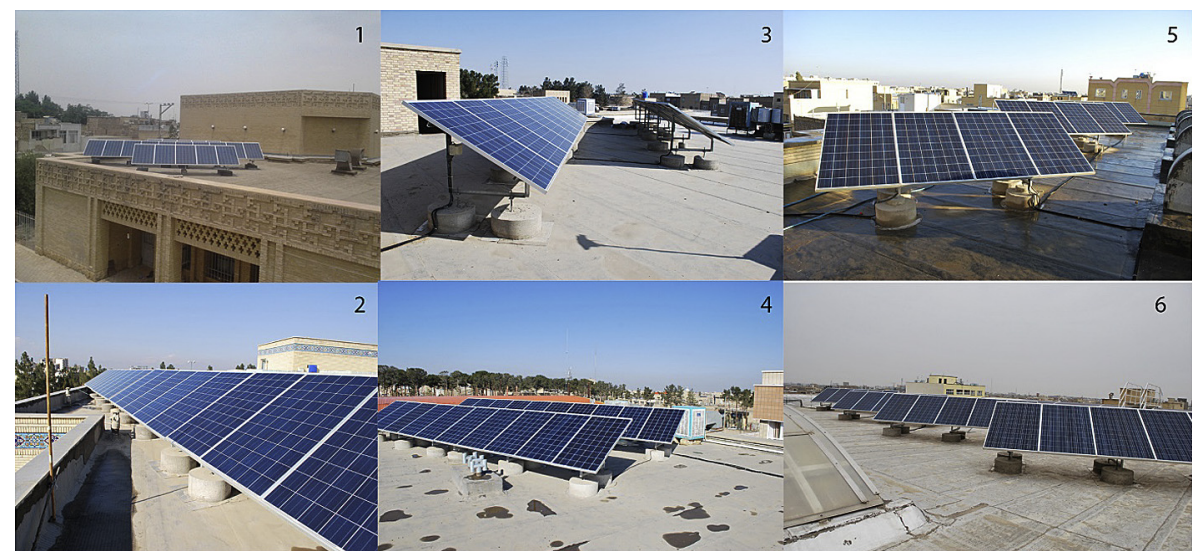

Fig. 4. Some of the case studies, various arrangements in different cases (1: 5-10-5; $2: 1 \times 20 ; 3,4: 2 \times 10 ; 5: 5 \times 4 ; 6: 4 \times 5$ ). 
Table 2

Monitored data of 14 rooftop PV systems installed in Kashan.

\begin{tabular}{|c|c|c|c|c|c|c|c|c|c|}
\hline $\begin{array}{l}\text { Pro } \\
\text { No. }\end{array}$ & Arrangement & $\begin{array}{l}\text { System } \\
\text { Capacity } \\
\text { Potential }(\mathrm{kW})\end{array}$ & $\begin{array}{l}\text { Total Energy } \\
\text { Produced (kWh), } \\
\text { Array output }\end{array}$ & $\begin{array}{l}\text { Initial Capital Cost (\$ per } \\
\text { capacity), Purchase and } \\
\text { Installation }\end{array}$ & $\begin{array}{l}\text { Cost Per } \\
\text { Unit } \\
(\$ / \mathrm{kW})\end{array}$ & $\begin{array}{l}\text { Annual } \\
\text { Revenue } \\
\text { (Income, \$) }\end{array}$ & $\begin{array}{l}\text { Annual Electricity } \\
\text { (kWh) (Current } \\
\text { Usage) }\end{array}$ & $\begin{array}{l}\text { Percent of } \\
\text { Annual } \\
\text { electricity }\end{array}$ & $\begin{array}{l}\text { Performance } \\
\text { Ratio (\%) }\end{array}$ \\
\hline 1 & $10,5,5$ & 5 & 8276 & 14,683 & 2937 & 1958 & 11,544 & $75 \%$ & $64 \%$ \\
\hline 2 & $10,5,5$ & 5 & 8349 & 14,678 & 2936 & 1975 & 9916 & $90 \%$ & $64 \%$ \\
\hline 3 & 10,10 & 5 & 8389 & 14,660 & 2932 & 1985 & 23,075 & $40 \%$ & $65 \%$ \\
\hline 4 & $10,5,5$ & 5 & 8758 & 14,674 & 2935 & 2072 & 16,292 & $59 \%$ & $68 \%$ \\
\hline 5 & 10,10 & 5 & 8452 & 14,662 & 2932 & 2000 & 16,650 & $55 \%$ & $65 \%$ \\
\hline 6 & $4,4,4,4,4$ & 5 & 8550 & 14,700 & 2940 & 2023 & 14,517 & $58 \%$ & $66 \%$ \\
\hline 7 & $5,5,5,5$ & 5 & 8569 & 14,680 & 2936 & 2027 & 51,260 & $18 \%$ & $66 \%$ \\
\hline 8 & 15,5 & 5 & 8827 & 14,648 & 2930 & 2088 & 24,560 & $39 \%$ & $68 \%$ \\
\hline 9 & 10,10 & 5 & 8878 & 14,652 & 2930 & 2101 & 17,409 & $51 \%$ & $68 \%$ \\
\hline 10 & 10,10 & 5 & 8949 & 14,665 & 2933 & 2117 & 5085 & $186 \%$ & $69 \%$ \\
\hline 11 & 20 & 5 & 9267 & 14,069 & 2814 & 2193 & 2172 & $34 \%$ & $71 \%$ \\
\hline 12 & 20 & 5 & 8851 & 14,632 & 2926 & 2094 & 24,566 & $38 \%$ & $68 \%$ \\
\hline 13 & 20 & 5 & 9287 & 14,632 & 2926 & 2197 & 36,640 & $25 \%$ & $72 \%$ \\
\hline 14 & 20 & 5 & 9400 & 14,632 & 2926 & 2224 & 8280 & $125 \%$ & $72 \%$ \\
\hline
\end{tabular}

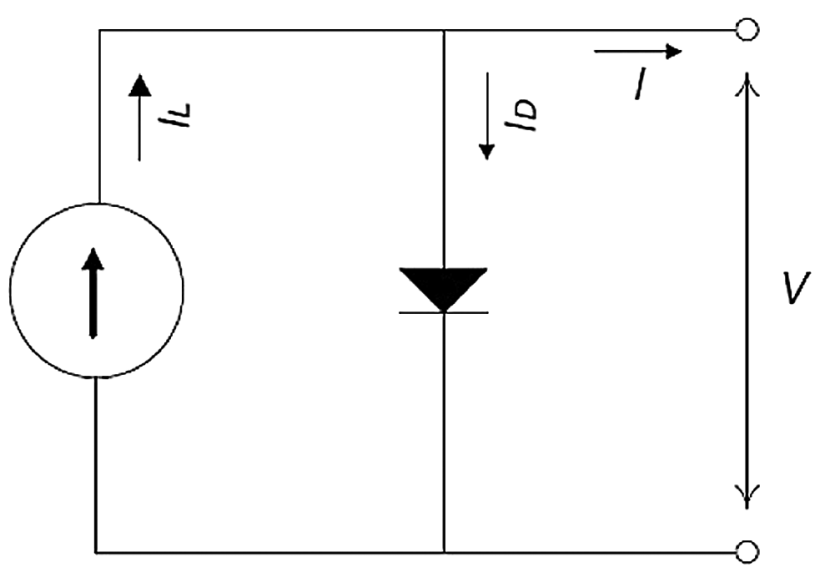

Fig. 5. Equivalent circuit in the four-parameter model (U.S. Department of Energy, 2012).

the panels. According to the results, temperature and irradiation of panels even with the same arrangements are different, in which the maximum amount of panel temperature recorded in case 12 and the maximum amount of irradiation on the panel occurred in case 14. The simultaneous effect of panel temperature and configuration on electricity generation is about $3.81 \%$, while the effect of different irradiation in addition to the effect of panel configuration calculated about $5.29 \%$, in comparison to the overall energy generation

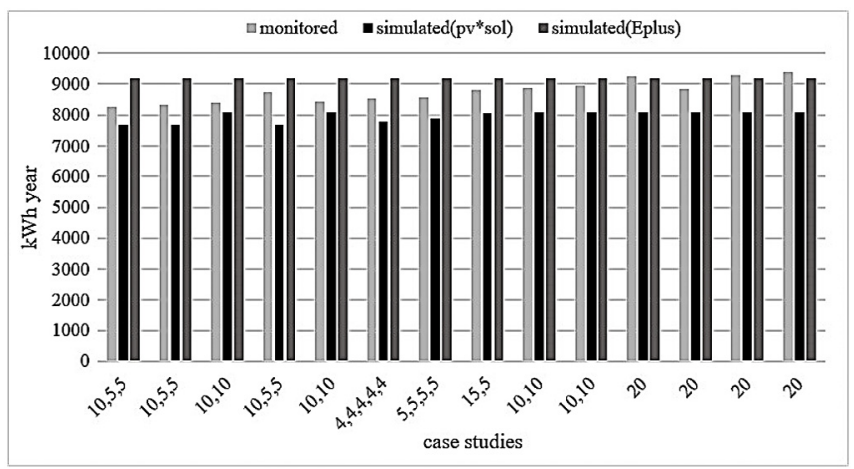

Fig. 6. Measured and simulated energy generation of PV systems with different arrays. differs $12.2 \%$, as above mentioned. However, this difference is less than $10 \%$ in panels with the same arrangements.

Results of EnergyPlus simulation are not different for various PV arrangements and are constant in all cases, Fig. 6. Simulated generated electricity equals to $9178 \mathrm{kWh}$ which is about $97.3 \%$ of the abovementioned maximum generated electricity and $110.8 \%$ of the minimum, respectively. Minimum and maximum difference between monitored and simulated results is observed in $1 \times 20$ and $10 \times 5 \times 5$ configurations, which equals to $2.65 \%$ underestimation and $10.89 \%$ overestimation, respectively, Fig. 6 . All four cases with $1 \times 20$ configurations have generated more energy than what expected by simulations which is due to their configurations. However, PV*SOL results differ by configuration, i.e., $1 \times 20$ module generate maximum energy and $10 \times 5 \times 5$ module produce minimum energy. The difference between monitored and simulated energy production equals to $3-13 \%$ with the average of $9 \%$, in line with previous studies (Accuracy analysis of software for the estimation and planning of photovoltaic installations, 2014). While EnergyPlus mostly overestimates produced energy, PV*SOL underestimates electricity energy generation. Apart from factors like cabling, maintenance, inverters' loss, etc. that increase deviation in simulation results, different shading hours, due to different arrangements, is another main factor which causes discrepancies.

"Percent of Annual electricity" in Table 2 shows a large difference between produced electricity and current usage of the school in some cases, for instance case 2. Case studies are all one to three story schools, with large unshaded flat roofs on which more number of PV panels could be installed. Percent of Annual electricity could be greater for most cases if higher number of PV panels were installed.

The performance ratio is a measure of the quality of a PV plant that is independent of location and is therefore often described as a quality factor. The performance ratio (PR) is stated as percent and describes the relationship between the actual and theoretical energy outputs of the PV plant (SMA Solar Technology AG, 2015). The closer PR value is to $100 \%$ for a PV plant, the more efficient it is operating. The performance ratio (PR) is calculated for each case using eq (1). $P_{S}$ is the total output measured energy $(\mathrm{kWh}), \mathrm{I}$ is Irradiance $\left(\mathrm{kWh} / \mathrm{m}^{2}\right), A$ is the area of array $\left(\mathrm{m}^{2}\right)$ and $E_{\mathrm{s}}$ is the efficiency of the panel.

$$
P R=\frac{P_{S}}{\left(I * A * E_{S}\right) * 100}
$$

PR ranges from 64 to $72 \%$ in different studied cases, with the highest value for the $1 \times 20$ arrangement. Thermal losses due to 


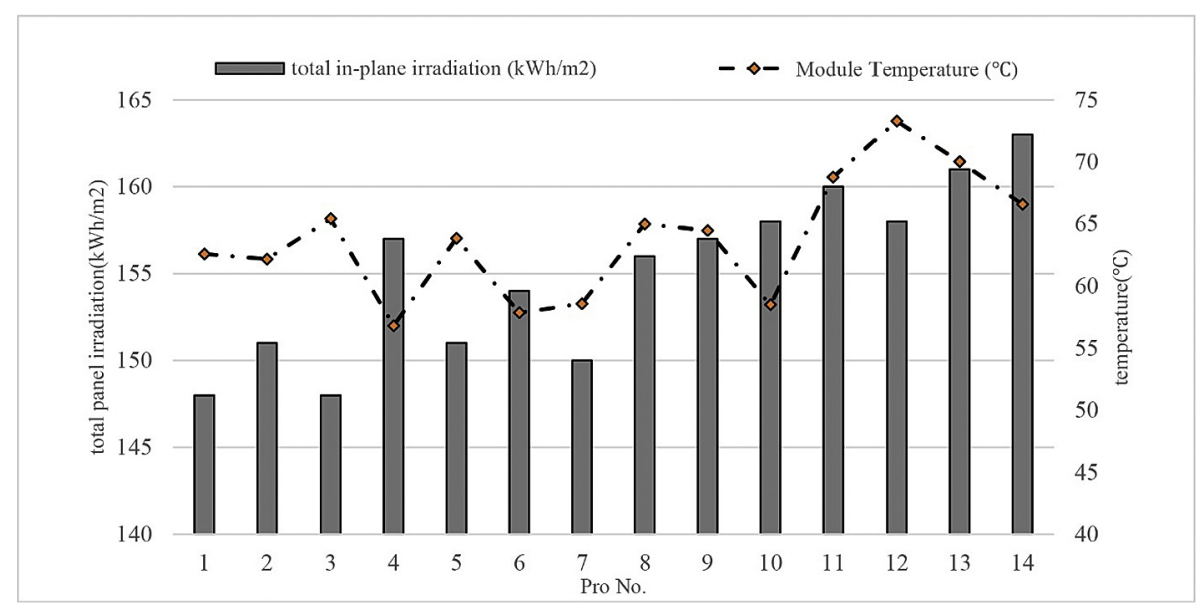

Fig. 7. Annual total panel irradiation and maximum module temperature in different cases.

solar panel heating, especially in summer is the main reason for the low performance ratio.

\subsection{Environmental performance}

Since electricity generated by PV systems don't require fossil fuels, its $\mathrm{CO}_{2}$ emission is much lower. The environmental benefits of PV panels and their effect on $\mathrm{CO}_{2}$ emission has been studied by many researchers (Quansah and Adaramola, 2016; U.S. Department of Energy, 2012; Freeman et al., 2014; Fu et al., 2015; Cucchiella et al., 2015). According to the study by Noorpoor and Kudahi (2015), average specific $\mathrm{CO}_{2}$ emission factor is estimated to be $571.29 \mathrm{~g} / \mathrm{kWh}$ in Iran (Noorpoor and Kudahi, 2015). Considering this factor, $\mathrm{CO}_{2}$ emission reduction has been calculated for each school at the end of 25 years (Fig. 8). Each PV system can averagely reduce $500 \mathrm{~kg} \mathrm{CO}_{2}$ emission in the first year of installation in each school. During life time of PV panels, these 14 schools can approximately reduce $1,613,900 \mathrm{~kg}$ of $\mathrm{CO}_{2}$ emission.

\subsection{Economic performance}

The economic performance of the PV systems is evaluated by four parameters; Net Present Value, Payback period, Return of investment and Levelized cost of energy. Electricity per unit costs of the panels in actual and subsidized tariffs are investigated by considering the following issues:

- Electricity production of each PV system is extrapolated using field measurement data from August 2014 to August 2015, and the annual deterioration rate of $0.7 \%$ which is assumed to be constant, Table 3.

- Annual management and maintenance costs are $0.1 \%$ of the investment cost. The maintenance and service costs increase by $2 \%$ each year (Abbaspour and Hennicke, 2005).

- Replacement of equipment (1\% of the PV panels annually, invertors every five years), considering annual decreasing rate of equipment costs (11\% incorporated to the 2014 cost).

- The cost of producing $1 \mathrm{kWh}$ electricity is presumed to be fixed during 25 years (around $0.21 \$$ ).

- $6.6 \%$ increase in annual school electricity price by considering the rate of energy price over the last 15 years, Fig. 9.

Economic performance of PV systems under actual electricity per unit costs without subsidies shows that payback periods range from 10.5 to 12.3 years with the average of 11.6 years for a $5 \mathrm{~kW}$ system, meaning that it takes 11.6 years to offset the initial costs, Table 3. ROI values (eq. (2)) range from 2.6 to 3.2, with the average of 2.9 for a $5 \mathrm{~kW}$ system, suggesting that the system provides

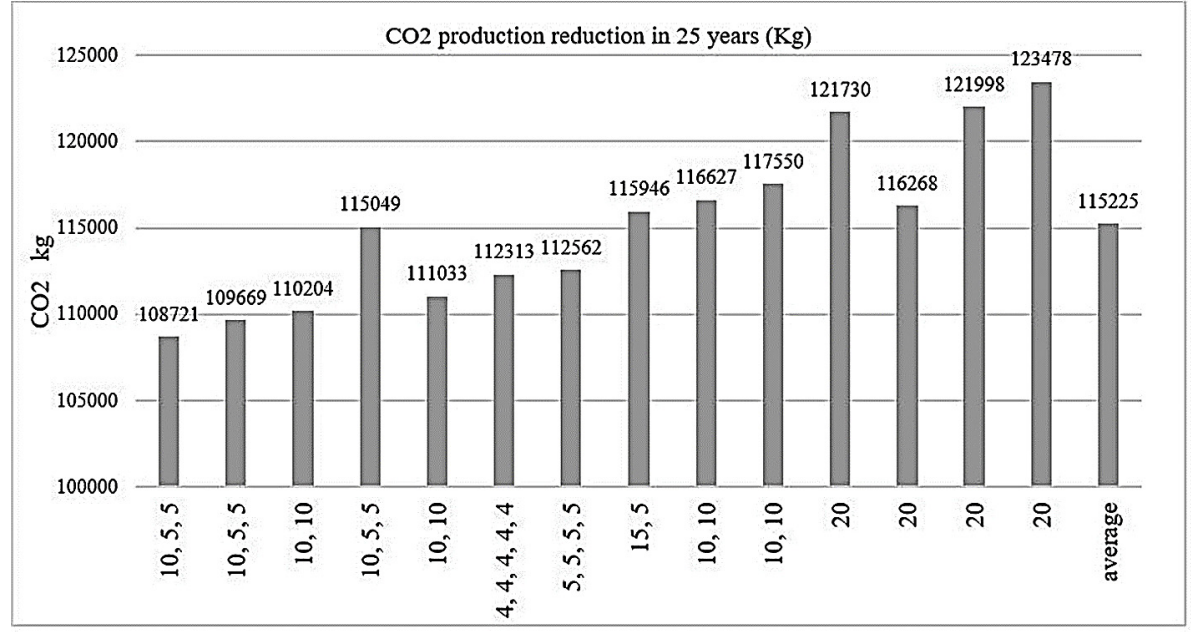

Fig. 8. Reduction in $\mathrm{CO} 2$ emission $(\mathrm{Kg})$ at the end of 25 years. 
Table 3

Shows economic performance of PV panels under actual electricity per unit costs and under subsidized average tariffs.

\begin{tabular}{|c|c|c|c|c|c|c|c|c|c|}
\hline Pro No. & $\begin{array}{l}\text { Actual or } \\
\text { Subsidized }\end{array}$ & $\begin{array}{l}\text { Initial Capital } \\
\text { Cost }(\$)\end{array}$ & $\begin{array}{l}\text { Estimated Total Electricity } \\
\text { Generated in } 25 \mathrm{Y}(\mathrm{kWh})\end{array}$ & $\begin{array}{l}\text { Cost Investment } \\
\text { Requires }\end{array}$ & $\begin{array}{l}\text { Cash Generated by } \\
\text { investment in } 25 \mathrm{Y}(\$)\end{array}$ & $\mathrm{NCF}$ & NPV & PBP & ROI \\
\hline \multirow[t]{2}{*}{1} & Actual & 14,652 & 204,251 & 5769 & 48,325 & 42,556 & 27,904 & 11.5 & 2.9 \\
\hline & Subsidized & & & & 4528 & -1241 & -15893 & 48.0 & -0.08 \\
\hline \multirow[t]{2}{*}{2} & Actual & 14,069 & 213,187 & 5752 & 50,440 & 44,688 & 30,619 & 10.5 & 3.2 \\
\hline & Subsidized & & & & 4726 & -1026 & -15095 & 46.9 & -0.07 \\
\hline \multirow[t]{2}{*}{3} & Actual & 14,683 & 190,404 & 5770 & 45,049 & 39,279 & 24,596 & 12.4 & 2.7 \\
\hline & Subsidized & & & & 4221 & -1549 & -16232 & 49.2 & -0.11 \\
\hline \multirow[t]{2}{*}{4} & Actual & 14,632 & 203,621 & 5769 & 48,176 & 42,407 & 27,775 & 11.5 & 2.9 \\
\hline & Subsidized & & & & 4514 & -1255 & -15887 & 48.2 & -0.09 \\
\hline \multirow[t]{2}{*}{5} & Actual & 14,648 & 203,058 & 5769 & 48,043 & 42,274 & 27,626 & 11.6 & 2.9 \\
\hline & Subsidized & & & & 4501 & -1268 & -15916 & 48.2 & -0.09 \\
\hline \multirow[t]{2}{*}{6} & Actual & 14,660 & 193,001 & 5770 & 45,664 & 39,894 & 25,234 & 12.1 & 2.7 \\
\hline & Subsidized & & & & 4279 & -1491 & -16151 & 49.1 & -0.10 \\
\hline \multirow[t]{2}{*}{7} & Actual & 14,700 & 196,696 & 5771 & 46,538 & 40,767 & 26,067 & 12 & 2.8 \\
\hline & Subsidized & & & & 4360 & -1411 & -16111 & 49.2 & -0.10 \\
\hline \multirow[t]{2}{*}{8} & Actual & 14,674 & 201,486 & 5770 & 47,671 & 41,901 & 27,227 & 11.7 & 2.9 \\
\hline & Subsidized & & & & 4467 & -1303 & -15977 & 47.8 & -0.09 \\
\hline \multirow[t]{2}{*}{9} & Actual & 14,632 & 213,657 & 5769 & 50,551 & 44,782 & 30,150 & 11 & 3.1 \\
\hline & Subsidized & & & & 4736 & -1033 & -15665 & 47.3 & -0.07 \\
\hline \multirow[t]{2}{*}{10} & Actual & 14,680 & 197,131 & 5770 & 46,641 & 40,871 & 26,191 & 11.9 & 2.8 \\
\hline & Subsidized & & & & 4370 & -1400 & -16080 & 48.7 & -0.10 \\
\hline \multirow[t]{2}{*}{11} & Actual & 14,665 & 205,867 & 5770 & 48,708 & 42,938 & 28,273 & 11.4 & 2.9 \\
\hline & Subsidized & & & & 4564 & -1206 & -15871 & 47.9 & -0.08 \\
\hline \multirow[t]{2}{*}{12} & Actual & 14,678 & 192,065 & 5770 & 45,442 & 39,672 & 24,994 & 12.2 & 2.7 \\
\hline & Subsidized & & & & 4258 & -1512 & -16190 & 49.2 & -0.10 \\
\hline \multirow[t]{2}{*}{13} & Actual & 14,662 & 194,453 & 5770 & 46,007 & 40,237 & 25,575 & 12.1 & 2.7 \\
\hline & Subsidized & & & & 4311 & -1459 & -16121 & 48.9 & -0.10 \\
\hline \multirow[t]{2}{*}{14} & Actual & 14,632 & 216,248 & 5769 & 51,164 & 45,395 & 30,763 & 10.8 & 3.1 \\
\hline & Subsidized & & & & 4794 & -975 & -15607 & 47.1 & -0.07 \\
\hline
\end{tabular}

around three times more savings than the initial capital cost. Although the systems do not have a large capacity, the results show economic convenience of PV panels under actual electricity per unit costs.

ROI $=($ Gain from investment - Cost of investment $) /$ Cost of investment

Payback periods range from 46.9 to 50.5 years under subsidized average tariffs, around twice the lifetime of PV panels. ROI values range from $-0.07 t^{0}-0.22$ years, suggesting that the initial capital costs are 4.6-15 times higher than systems' savings. The cash generated by investment cannot even offset the costs that the investment requires during 25 years. Net Cash Flow is the Net Income plus the Depreciation Net Present Value (NPV) is the difference between the present value of cash inflows and the present value of cash outflows (eq. (3)). $C_{0}$ is the initial investment cost, $\mathrm{Ct}$ is the net cash inflow during the period t, $N_{y}$ is the Life time and i is the

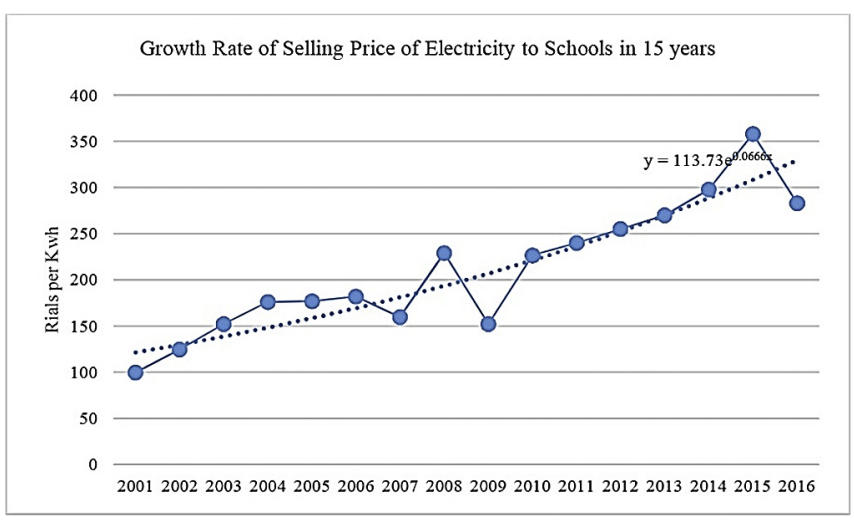

Fig. 9. A yearly increasing of $6.6 \%$ in the prices of electricity. discount rate. NPV is used in capital budgeting to analyze the profitability of a projected investment or project to see if the generated benefits are greater than the costs or not. Thus, the larger and the more positive NPV is, the more economical the investment is.

$N P V=\sum_{t=1}^{N_{Y}} \frac{C_{t}}{(1+i)^{t}}-C_{0}$

Net Cash Flow and Net Present Value are both negative, Table 3. If schools invest in a $5 \mathrm{~kW}$ system, they will averagely lose around $15,100 \$$, but if the government invests in a $5 \mathrm{~kW}$ system, they will averagely gain around $27,357 \$$. Results show poor economic performance of PV panels under subsidized average tariffs and why public schools do not invest in these systems. Figs. 10 and 11 clearly explain economic performance of PV panels under both real prices and subsidized prices.

The levelized cost of energy (LCOE) is also calculated to show net present value of generated electricity unit-cost over a twenty years lifetime period of the panels. It is affected by combination of capital costs, operations and maintenance $(\mathrm{O} \& \mathrm{M})$, performance, and fuel costs. Using the NREL levelized cost of energy calculator, the LCOE is $78.5 \mathrm{cent} / \mathrm{kWh}$ which equals to 31.9 cent $/ \mathrm{kWh}$ in Simple Levelized Cost of Renewable Energy (cents/kWh) (Levelized Cost of Energy Calculator). Results show that electricity generated by solar PVs is more expensive than small hydro and wind electricity in Iran which are 15.4 and 18.26 cents/kWh, respectively (Barimani, 2016).

\section{Discussion}

According to the results, generated electricity of the PV systems does not have any correlation with schools' energy consumption; the generated energy accounts for $18 \%-186 \%$ of the annual energy consumption of the schools (8569-8949 kWh). This shows that no feasibility study is done for deciding upon power capacity of the 


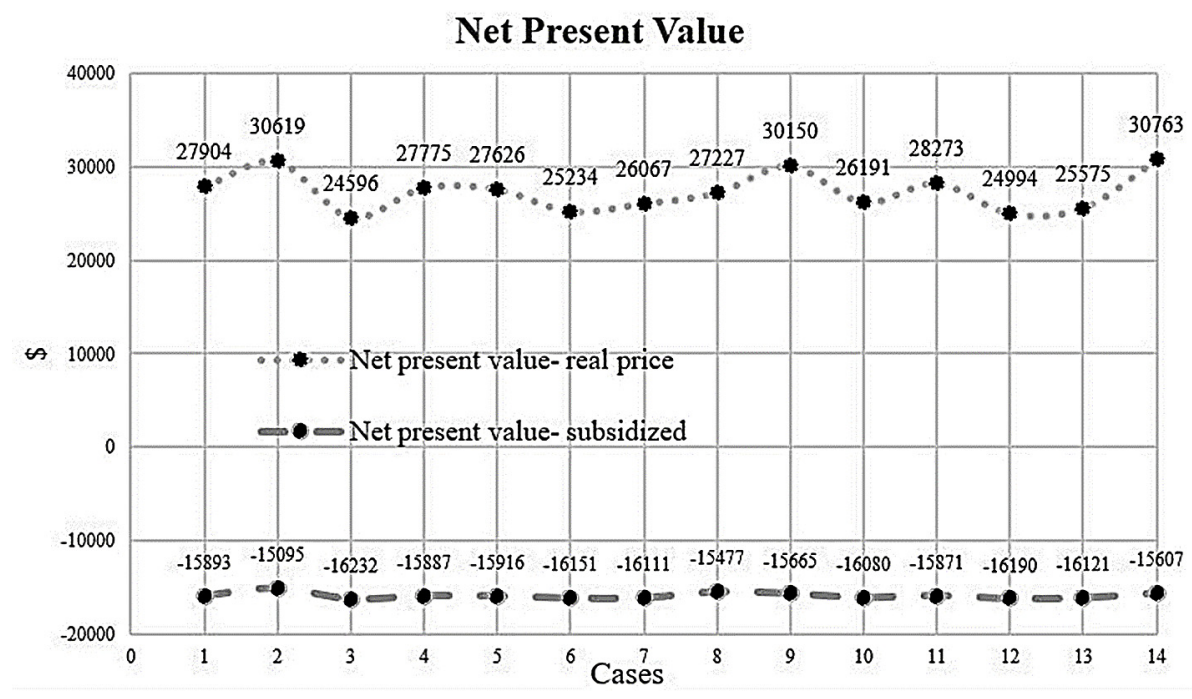

Fig. 10. Net Present Value of PV systems.

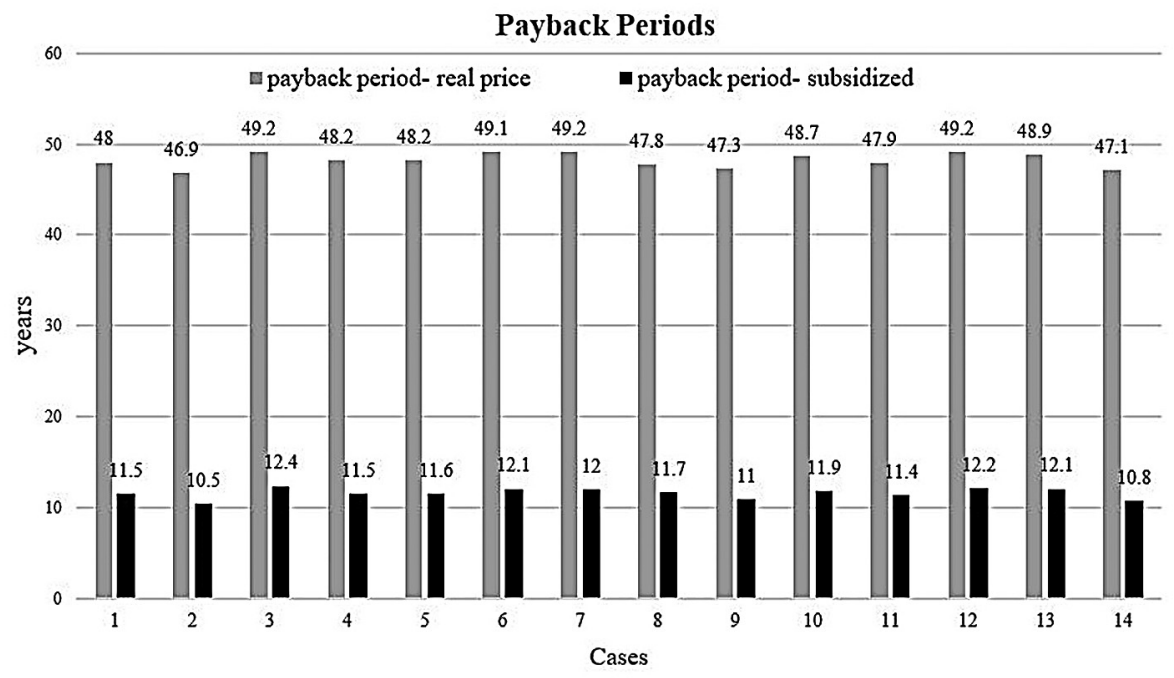

Fig. 11. Payback periods of PV systems.

systems.

Regarding panels' output, lower energy generation of split PV arrays can be described by energy loss in wiring and voltage intolerance due to partial shading. The shading can affect energy efficiencies of the system with the most important effect in case of horizontal shading (Bayrak et al., 2017). However, this effect cannot be shown by all software such as Energy plus. Simulation results could be considered a method of bracketing the upper end of electricity production rather than an accurate prediction of what the panels will produce in a real installation.

Comparing average performance ratio of grid connected PV panels in different countries (Ayompe et al., 2011; Kymakis et al., 2009; Decker and Jahn, 1997; Sidrach-de-Cardona and Mora López, 1999; Drifet al, 2007; Mondol et al., 2006; Pietruszko and Gradzki, 2003; De Miguel et al., 2002; Chokmaviroj et al., 2006) shows that performance ratio of the present study (67.6\%) stands in between and is close to the average of these ten cases which is $69 \%$ (Fig. 12). This ratio can be increased by designing arrays more efficiently and cleaning tiles. Comparing payback period of PV panels in different countries (Liu et al., 2015; Al-Salaymeh et al., 2010; Quansah and Adaramola, 2016; Bianchini et al., 2016; Fathabadi, 2016a, 2016b; Hammad et al., 2017), shows that apart from solar potentials of each country, many factors including the type of panel, its material, its capacity, inflation rate and country's policies can make a huge difference in payback periods (2.3-60 years), as shown in Fig. 13.

Barriers to adoption of PV technology vary across context (Noorpoor and Kudahi, 2015), as the acceptability does. The policies in different countries are mostly based on financial aspects, such as subsidy policy (governmental consumers and product subsidies), tax policies, especially using polluter-pays system, and monetary policy (such as low-interest loans or export credits), and finally price policies (even fixed or floating price (Shuiying et al., 2011). Germany, China, Japan, Italy (Di Dio et al., 2015) and Portugal (Behrens et al., 2016) are among countries making efforts to switch to renewable energy sources by adopting broad range of policies including feed-in tariffs (FITs), tendering, net metering and fiscal incentives. However, tenders (competitive bidding or auctions) for 


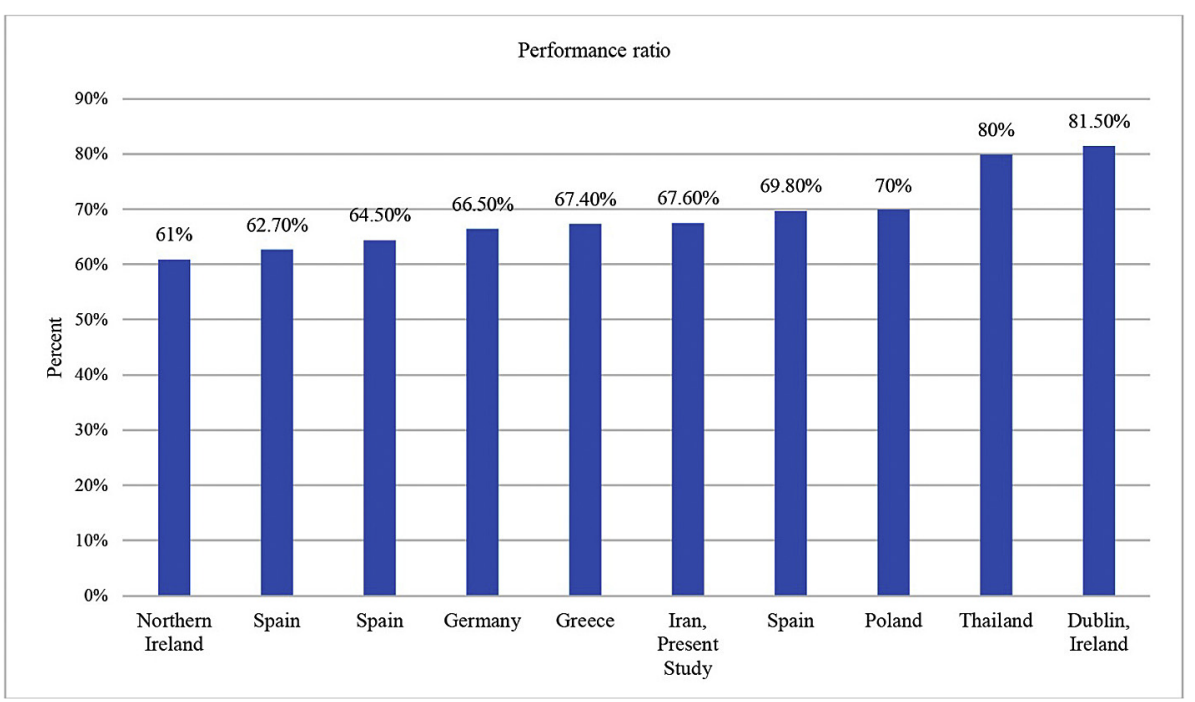

Fig. 12. Shows performance ratio of grid connected PV panels in different countries.

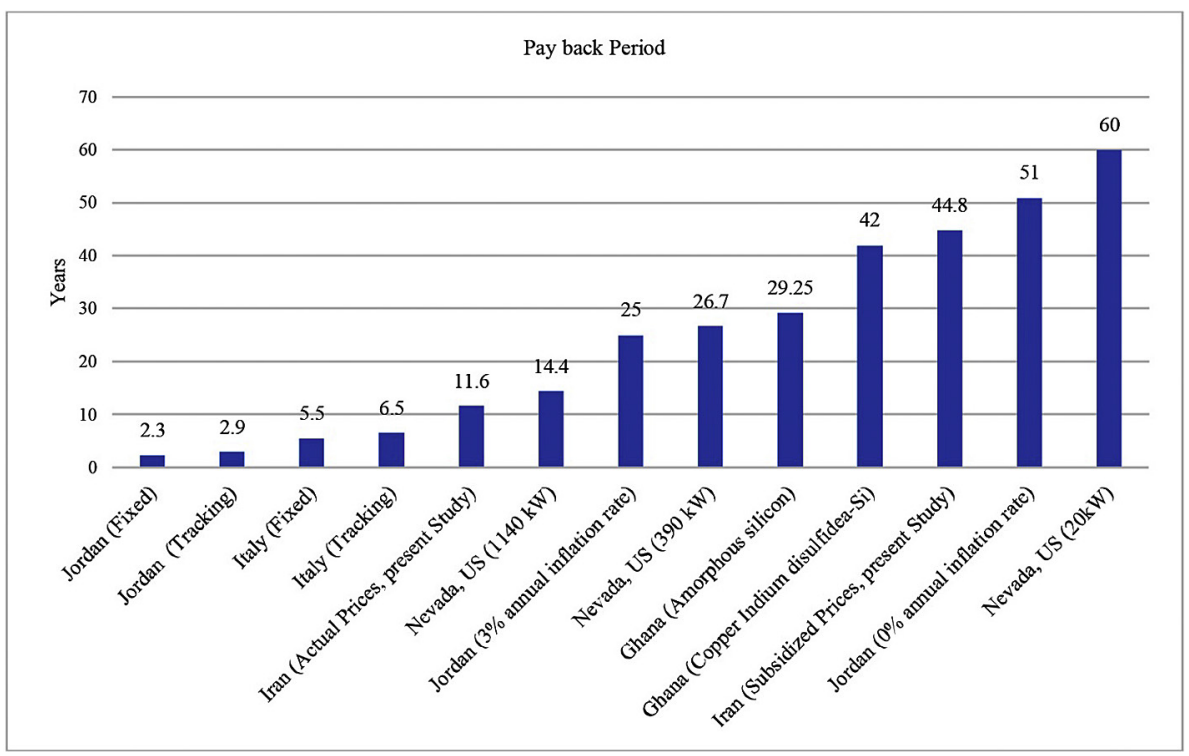

Fig. 13. Shows payback period of different PV panels in different countries.

renewable energy are the most rapidly expanding form of support for renewable energy project deployment and are becoming the preferred policy tool for large-scale projects (Levelized Cost of Energy Calculator). FITs are the most widely utilized form of regulative support to the renewable power sector. According to (Campoccia et al., 2007), FIT for Field Installed PV(FIPV) systems are not convenient in Germany and in France. However, in Spain FIT are very convenient only when the rated PV power is smaller than $100 \mathrm{kWpp}$ (because of the different values of feed-in tariffs). In Italy FIT for FIPV systems are convenient for all the rated installed PV powers. Moreover, FIT for Building Integrated PV Systems (BIPV) systems are convenient for all the EU countries, except in Spain when the installed PV power is over $100 \mathrm{kWpp}$. In England (StrielkowskiŠ. Dalia and Bilan, 2017), new uses of the traditional electricity market and tariffs has created many promising opportunities for reallocating charges from the existing users who may be poor and vulnerable. In Portugal, the combined historical renewable energy policy and renewable energy developments yielded a clear reduction in emissions, in excess of 7.2 MtCO2eq, an increase in GDP of $1557 \mathrm{M} €$, and a creation of 160 thousand jobyears (Behrens et al., 2016). In Italy (Di Dio et al., 2015), during an eight year experience on PV panels, named “Conto Energia”, a lot of changes were made in the mechanism to solve the uncertainty due to lack of data i.e., simplified authorization, facilitate the spread of the connection and commercial relationship between the producer and the electricity provider which allow a direct profit to be made from the PV energy production.

Results show a significant difference between economic performance under actual electricity per unit costs without subsidies and economic performance under subsidized average tariffs which can be contributed to the wrong policies adopted for electricity and PV systems. States' financial support plays a key role in development of these systems, since without adopting such policies, the high initial costs of PV panels discourage consumers to replace electricity from fossil fuels with clean electricity. Deployment policies have been established all over the world which resulted in 
a positive growth in annual installation from $2.67 \mathrm{GW}$ in 2007 to $37.6 \mathrm{GW}$ in 2013 (Jia et al., 2016). The government in Iran has also adopted some supporting policies for the development of PV panels, including revised Feed in Tariffs, National Development Fund (allocating oil and gas revenues to finance renewable energy projects) and the Budget for purchasing Renewable Energy Electricity (Bernal-Agustín and Dufo-López, 2006). However, to make PV panels more economically viable and to make them able compete with conventional electricity resources, following policies are recommended.

- In February 2010, an energy price reform happened in Iran to manage the increasing trend of energy; however, $90 \%$ of the revenue from the subsidy removal was allocated to the household cash rebate program (Zahedi, 2010). By removing subsidies, part of the revenue can be allocated to provide low interest loans for purchasing and installing PV panels, subsidizing producers of PV panels and consumers of clean electricity.

- To reach the real prices, subsidies for electricity and fuels should be reduced gradually as supported in (Abbaspour and Hennicke, 2005), since fossil-fuel subsidies prevent the deployment and development of PV panels. By this policy, the huge financial burden on the government for subsidies can also be decreased.

- Another strategy is to exempt tax for consumers and producers of non-fuel electricity.

- Deploying PV panels in commercial sector instead of low energy price educational buildings results in lower payback period and better economic performance.

- As supported in (Zahedi, 2010), serious structural changes should be made to help the private sector play a more decisive role in the economy since the energy market is virtually managed by the public sector. If producing fuel electricity could be run by private sectors, the government could consider taxes on fossil fuel pollution like releasing $\mathrm{CO}_{2}$.

- Designing PV farms with less vital substructures in Iran's deserts with long sunshine hours seems like a profitable solution to take advantage of the potentials of this country and reduce payback period of these systems. However, the price of energy transfer should be considered in such cases.

- Integrating these panels into buildings can also replace common building elements like shading devices, façade elements and roofing materials, therefore can improve economic feasibility of the projects, as supported in (Zahedi, 2010; Bridle and Kitson, 2014). By considering a separation between PV panels and the wall, the air can cool down the temperature of PV panel and absorb heat away from the PV panels (Baljit et al., 2016), which can increase their energy performance.

- Public acceptance is an important factor that can be achieved by raising public awareness about the benefits of these systems and the disadvantages of fossil fuel electricity. Encouraging polices toward this source of energy include discounts on water and gas bills for consumers of clean energy since solar electricity does not require water, and guaranteeing maintenance and operation costs of these systems.

These strategies should be considered by the government to remove barriers to clean energy and to take advantage of numerous economic and environmental benefits that PV panels offer. For policy makers who are interested in reducing carbon emissions and dependence on fuel-based electricity, the deployment of PV panels may be a very good solution. Investing in PV systems can also create more job opportunities, as confirmed in (Abbaspour and Hennicke, 2005), which in turn leads to better economic situation of the country. Overall, highly subsidized price of energy, centralized ownership of main energy resources in Iran, limited access to international finance, high inflation rates, limited knowledge on technology and installation impede PV panels' development.

For reducing electricity usage and air pollution, energy consumption and energy efficiency in schools should also be closely examined and improved; like considering the efficiency of electrical appliances and insulations. To decrease air pollution, the efficiency of power stations should be increased, technical problems should be removed and electricity transmission losses should be decreased. By this policy, the price of producing $1 \mathrm{kWh}$ electricity also declines, and the gap between the prices paid by consumers and the real prices decreases. It is worth mentioning that applying the experience of successful countries in terms of solar systems and PV panels leads to a faster growth of these systems.

\section{Conclusion}

Sustainable forms of energy should guarantee both economic feasibility of the investment and efficient electricity generation which are both so crucial in the advent of new technologies. In recent years, economic and environmental features of PV panels have drawn the attention of designers, policy makers, and engineers.

The price of electricity for schools is highly subsidized which is mainly due to the policy of providing cheap education for students. Highly subsidized electricity for schools, environmental concerns and social aspects are among incentives that have encouraged the government to install these panels on the roof of public schools. Considering the real price of fuels, $1 \mathrm{~kW}$ h electricity costs $0.21 \$$ in Iran, approximately 25 times higher than what schools pay averagely for, $0.011 \$$. The results of this study show that the economic performance of PV panels does not encourage consumers of fossil fuel electricity to install these systems. However, these systems are quite economically viable for the state. Results show a significant difference between economic performance under actual electricity per unit costs without subsidies, PBP ranging from 10.5 to 12.3 years, and economic performance under subsidized average tariffs, PBP ranging from 46.9 to 50.5 years. Under subsidized prices, NCF and NPV are both negative and the cash generated by investment cannot even offset the costs that the investment requires during 25 years. Accordingly, the study discusses the policies that can make PV panels more economically viable. Further studies are required to investigate economic performance of PV panels in Housing, Industrial sector and in Universities.

\section{Acknowledgements}

The authors would like to acknowledge support from Sialk Solar Company and helpful advice from Mr. A. Sarafraz.

\section{References}

Abbaspour, M., Hennicke, P., 2005. Climate policy and sustainable development: opportunities for Iranian-German cooperation, case study: solar thermal energy in Iran. Cent. Environ. Energy Res. Stud. Data Rep. Teheran 11-15.

Adam, A.D., Apaydin, G., 2016. Grid connected solar photovoltaic system as a tool for green house gas emission reduction in Turkey. Renew. Sustain. Energy Rev. 53, 1086-1091.

Al-Salaymeh, A., Al-Hamamre, Z., Sharaf, F., Abdelkader, M.R., 2010. "Technical and economical assessment of the utilization of photovoltaic systems in residential buildings: the case of Jordan. Energy Convers. Manag. 51 (8), 1719-1726.

Alamdari, P., Nematollahi, O., Mirhosseini, M., 2012. "Assessment of wind energy in Iran: a review. Renew. Sustain. Energy Rev. 16 (1), 836-860.

Ayompe, L.M., Duffy, A., McCormack, S.J., Conlon, M., 2011. “Measured performance of a $1.72 \mathrm{~kW}$ rooftop grid connected photovoltaic system in Ireland. Energy Convers. Manag. 52 (2), 816-825.

Baljit, S.S.S., Chan, H.-Y., Sopian, K., 2016. Review of building integrated applications of photovoltaic and solar thermal systems. J. Clean. Prod. 137, 677-689.

Barimani, M., 2016. Cost-benefit analysis of renewable power under full subsidy 
targeting law enforcement conditions in Iran. Int. J. Energy Econ. Policy 6 (1), 105-112.

Bayrak, F., Ertürk, G., Oztop, H.F., 2017. Effects of partial shading on energy and exergy efficiencies for photovoltaic panels. J. Clean. Prod. 164, 58-69.

Behrens, P., Rodrigues, J.F.D., Brás, T., Silva, C., 2016. Environmental, economic, and social impacts of feed-in tariffs: a Portuguese perspective $2000-2010$. Appl. Energy 173, 309-319.

Bernal-Agustín, J.L., Dufo-López, R., 2006. Economical and environmental analysis of grid connected photovoltaic systems in Spain. Renew. energy 31 (8), 1107-1128.

Bianchini, A., Gambuti, M., Pellegrini, M., Saccani, C., 2016. Performance analysis and economic assessment of different photovoltaic technologies based on experimental measurements. Renew. Energy 85, 1-11.

Branker, K., Pathak, M.J.M., Pearce, J.M., 2011. A review of solar photovoltaic levelized cost of electricity. Renew. Sustain. Energy Rev. 15 (9), 4470-4482.

Bridle, R., Kitson, L., 2014. The Impact of Fossil-fuel Subsidies on Renewable Electricity Generation.

Campoccia, A., Dusonchet, L., Telaretti, E., Zizzo, G., 2007. Feed-in Tariffs for Gridconnected PV Systems: the Situation in the European Community, pp. 1981-1986.

Chaharmahal Weather Station Website." .

Chokmaviroj, S., Wattanapong, R., Suchart, Y., 2006. Performance of a 500 kWP grid connected photovoltaic system at Mae Hong Son Province, Thailand. Renew. Energy 31 (1), 19-28.

Coughlin, J., Kandt, A., 2011. Solar schools assessment and implementation Project: financing options for solar Installations on $\mathrm{K}-12$. Contract 303.

Cucchiella, F., D'Adamo, I., Lenny Koh, S.C., 2015. Environmental and economic analysis of building integrated photovoltaic systems in Italian regions. J. Clean. Prod. 98, 241-252.

Curthoys, A., 2012. Solar Energy Generation Potential of Tompkins County. Ithaca.

De Miguel, A., Bilbao, J., Cazorro, J.R.S., Martin, C., 2002. Performance analysis of a grid-connected PV system in a rural 628 site in the northwest of Spain. In: World Renew. Energy Congr. VII no. Wrec.

Decker, B., Jahn, U., 1997. Performance of 170 grid connected PV plants in northern Germany - analysis of yields and optimization potentials. Sol. Energy 59 (4-6-6 pt 4), 127-133.

Di Dio, V., Favuzza, S., La Cascia, D., Massaro, F., Zizzo, G., 2015. Critical assessment of support for the evolution of photovoltaics and feed-in tariff ( $\mathrm{s}$ ) in Italy. Sustain. Energy Technol. Assessments 9, 95-104.

Drif, M., et al., 2007. Univer Project. A grid connected photovoltaic system of 200 kWp at Ja??n University. Overview and performance analysis. Sol. Energy Mater. Sol. Cells 91 (8), 670-683.

El Chaar, L., Lamont, L.A., 2010. Global solar radiation: multiple on-site assessments in abu dhabi, UAE. Renew. energy 35 (7), 1596-1601.

Esen, M., Yuksel, T., 2013. Experimental evaluation of using various renewable energy sources for heating a greenhouse. Energy Build. 65, 340-351.

Esen, H., Inalli, M., Esen, M., 2006. Technoeconomic appraisal of a ground source heat pump system for a heating season in eastern Turkey. Energy Convers. Manag. 47 (9-10), 1281-1297.

Esen, H., Inalli, M., Esen, M., 2007. A techno-economic comparison of groundcoupled and air-coupled heat pump system for space cooling. Build. Environ. 42 (5), 1955-1965.

Esen, H., Esen, M., Ozsolak, O., 2017. Modelling and experimental performance analysis of solar-assisted ground source heat pump system. J. Exp. Theor. Artif. Intell. 29 (1), 1-17.

Fathabadi, H., 2016. Novel high efficient offline sensorless dual-axis solar tracker for using in photovoltaic systems and solar concentrators. Renew. Energy 95, 485-494.

Fathabadi, H., 2016. Comparative study between two novel sensorless and sensor based dual-axis solar trackers. Sol. Energy 138, 67-76.

Feldman, D., Barbose, G., Margolis, R., Wiser, R., Darghouth, N., Goodrich, A., 2012. Photovoltaic (PV) Pricing Trends: Historical, Recent, and Near-term Projections, pp. 1-30. NREL-DOE Tech. Rep., no. November.

Freeman, J., Blair, N., Dobos, A.P., 2014. Validation of Multiple Tools for Flat Plate Photovoltaic Modeling against Measured Data. Technical Report NREL/TP-6A2061497.

Fthenakis, V.M., Kim, H.C., Alsema, E., 2008. Emissions from photovoltaic life cycles. Environ. Sci. Technol. 42 (6), 2168-2174.

Fu, Y., Liu, X., Yuan, Z., 2015. Life-cycle assessment of multi-crystalline photovoltaic (PV) systems in China. J. Clean. Prod. 86, 180-190.

G. German Solar Association, BSW-Solar,Berlin, 2016. Enabling PV Iran: the Emerging PV Market in Iran.

Griffith, B.T., Ellis, P.G., 2004. Photovoltaic and solar thermal modeling with the
EnergyPlus calculation engine. World Renew. Energy Congr. VIII Expo. 1-5. Denver, Color. August 29-September 3, no. July.

Hammad, B., Al-Sardeah, A., Al-Abed, M., Nijmeh, S., Al-Ghandoor, A., 2017. Performance and economic comparison of fixed and tracking photovoltaic systems in Jordan. Renew. Sustain. Energy Rev. 80 (May), 827-839.

Hestnes, A.G., 1999. Building integration of solar energy systems. Sol. Energy 67 (4), $181-187$.

Hsu, C.W., 2012. Using a system dynamics model to assess the effects of capital subsidies and feed-in tariffs on solar PV installations. Appl. Energy 100, 205-217.

IEA, 2016. World Energy Statistics.

"Irradiation data for every place on Earth".

Jia, F., Sun, H., Koh, L., 2016. Global solar photovoltaic industry: an overview and national competitiveness of Taiwan. J. Clean. Prod. 126, 550-562.

Kandt, A., 2011. Solar for Schools: a Case Study in Identifying and Implementing Solar Photovoltaic (PV) Projects in Three California School Districts. Preprint. National Renewable Energy Laboratory.

Kannan, R., Leong, K.C., Osman, R., Ho, H.K., Tso, C.P., 2006. Life cycle assessment study of solar PV systems: an example of a $2.7 \mathrm{~kW}$ p distributed solar PV system in Singapore. Sol. Energy 80 (5), 555-563.

Kazemi, H., Zahedi, A., 2002. Wind and solar energy developments in Iran. In: Australasian Universities Power Engineering Conference (AUPEC), vol. 4. Melbourne, Australia.

Kim, H., Cha, K., Fthenakis, V.M., Sinha, P., Hur, T., 2014. Life cycle assessment of cadmium telluride photovoltaic (CdTe PV) systems. Sol. Energy 103, 78-88.

Kymakis, E., Kalykakis, S., Papazoglou, T.M., 2009. Performance analysis of a grid connected photovoltaic park on the island of Crete. Energy Convers. Manag. 50 (3), 433-438.

“Levelized Cost of Energy Calculator." .

Liu, X., Hoekman, S.K., Robbins, C., Ross, P., 2015. Lifecycle climate impacts and economic performance of commercial-scale solar PV systems: a study of PV systems at Nevada's Desert Research Institute (DRI). Sol. Energy 119, 561-572.

Mondol, J.D., Yohanis, Y., Smyth, M., Norton, B., 2006. Long term performance analysis of a grid connected photovoltaic system in Northern Ireland. Energy Convers. Manag. 47 (18-19), 2925-2947.

Moshiri, S., 2013. Energy price reform and energy efficiency in Iran. In: IAEE Energy Forum.

Noorpoor, A.R., Kudahi, S.N., 2015. CO 2 emissions from Iran's power sector and analysis of the influencing factors using the stochastic impacts by regression on population, affluence and technology (STIRPAT) model. Carbon Manag. 6 (3-4), $101-116$.

Orioli, A., Di Gangi, A., 2014. Review of the energy and economic parameters involved in the effectiveness of grid-connected PV systems installed in multistorey buildings. Appl. Energy 113, 955-969.

Pietruszko, S.M., Gradzki, M., 2003. Performance of a grid connected small PV system in Poland. Appl. Energy 74 (1-2), 177-184.

Pillai, G.G., Putrus, G.A., Georgitsioti, T., Pearsall, N.M., 2014. Near-term economic benefits from grid-connected residential PV (photovoltaic) systems. Energy 68, $832-843$.

Quansah, D.A., Adaramola, M.S., 2016. Economic assessment of a-Si and CIS thin film solar PV technologies in Ghana. Sustain. Energy Technol. Assessments 18, $164-174$.

Ren, H., Gao, W., Ruan, Y., 2009. Economic optimization and sensitivity analysis of photovoltaic system in residential buildings. Renew. energy 34 (3), 883-889.

Rose, A., Stoner, R., Pérez-Arriaga, I., 2016. Prospects for grid-connected solar PV in Kenya: a systems approach. Appl. Energy 161, 583-590.

Shuiying, Z., Chi, L., Liqiong, Q., 2011. Solar industry development and policy support in China. Energy Procedia 5, 768-773.

Sidrach-de-Cardona, M., Mora López, L., 1999. Performance analysis of a gridconnected photovoltaic system. Energy 24 (2), 93-102.

SMA Solar Technology AG, 2015. Performance Ratio, pp. 1-9.

Strielkowski, W., Dalia, Š., Bilan, Y., 2017. Network Charging and Residential Tariffs: a Case of Household Photovoltaics in the United Kingdom, vol. 77, pp. 461-473 no. April.

U.S. Department of Energy, 2012. Input Output Reference: the Encyclopedic Reference to Energy Plus Input and Output, No. C.

Zahedi, A., 2010. A review on feed-in tariff in Australia, what it is now and what it should be. Renew. Sustain. Energy Rev. 14 (9), 3252-3255.

"Accuracy analysis of software for the estimation and planning of photovoltaic installations," International J. Energy Environmental Engineering, vol. 5, no. 1, 2014.

“Retrieved from solargis," 2015. 